International Medical Society http://imedicalsociety.org

\title{
Educational Booklet on Neonatal Jaundice: an Approach for Caregivers

\begin{abstract}
Anna Virgínia Viana Cardoso Dantas ${ }^{1}$, Natália Barreto de Castro', Viviane Martins da Silva², Maria Vera Lúcia Moreira Leitão Cardoso²,
\end{abstract} Nirla Gomes Guedes², Marcos Venícios de Oliveira Lopes², Natália Oliveira de Araújo ${ }^{3}$

\section{Abstract}

Objective: To create an educational booklet on neonatal jaundice for newborns caregivers.

Method: This is a methodological research based on Echer recommendations, taking the following steps: search of the literature, selection of information on the subject, appropriateness of vocabulary, the selected content illustration and elaboration of guidelines.

Results: The results showed literature through an integrative review. There was an analysis of 13 selected articles, and the information content of the booklet was defined. This information was arranged in the form of dialogues in the active voice, using simple concepts of words, phrases, and explanatory illustrations.

Conclusion: Nurses should pierce the inherent scientific capacity of the profession and perform artistic skills able to educate health. Thus, the built booklet is a facilitator in the educational process to promote neonatal health.

\section{Introduction}

Neonatal jaundice is a clear clinical condition when serum bilirubin reaches levels above $5 \mathrm{mg} / \mathrm{dl}$ and the main manifestations are the yellowing of the skin, sclera, mucous membranes and body fluids [1-2]. During the first week of life, elevation of serum bilirubin levels affects $60 \%$ of newborns at term and $80 \% \%$ of preterm newborns [3]. High levels of bilirubin in newborns can cause irreversible neurological impairment in the system, such as the neonatal encephalopathy [4].
1 RN, Master's Degree Student, Graduate Program in Nursing, School of Nursing, Federal University of Ceará. Fortaleza, Ceará State, Brazil.

2 RN, PhD, Teacher, School of Nursing, Federal University of Ceará. Fortaleza, Ceará State, Brazil.

3 RN, Specializing in Intensive Care Unit, Federal University of Ceará. Fortaleza, Ceará State, Brazil.

Contact information:

\section{Anna Virgínia Viana Cardoso} Dantas.

Address: Nursing Department, Federal University of Ceará, 1115 Alexandre Baraúna st, Rodolfo Teófilo, Fortaleza, Ceará, Brazil 60430-160.

ほ annavirginiaviana@gmail.com

\section{Keywords}

Newborn; Neonatal Jaundice; Technology. 
According to the American Neonatologists Nurses Association, it is expected that about 5\% to $11 \%$ of children develop severe hyperbilirubinemia requiring phototherapy treatment [4]. In Brazil, from 2004 to 2013, neonatal jaundice and kernicterus were reported as the underlying cause of death in 1312 newborns [7]. Despite the relative reduction of cases in the country, the numbers still indicate a health condition concern to society.

Although it is a transient condition, neonatal jaundice is up to $75 \%$ of hospital readmissions in the first seven days of life [5]. The risk of readmission significantly increases the occurrence of early hospital discharge, which occurs up to 48 hours of the life of the newborn [6]. Usually, the affective and emotional problems for the mother and child arise due to the consequent separation of rehospitalization and maternal knowledge on the children's medical condition and their treatment options.

Clinical signs of jaundice and its complications can be evidenced after hospital discharge of newborns since the hospital stay of mother and child has been declining in recent decades. Thus, there has been an increase in the occurrence of jaundice unnoticed in the home environment, mainly due to the inability of caregivers to assess clinical changes in the neonate. Therefore, it is necessary to train those who provide care to the newborn at home, so that they can prevent and identify neonatal jaundice effectively.

During the hospitalization, the nurses are important in the planning for mother and newborn discharge, as they evaluate the safety and ability of mothers in taking care of themselves and their child, ensuring a follow-up skilled care, with adequate home care [8].

The process of adaptation to motherhood reveals parents doubts and feelings of inadequacy in new demands and obligations in the care of the newborn. Therefore, it is emphasized the need for guidance at this stage, to demystify the mistaken common sense and the trivialization of clinical signs.
During this period, it is essential to provide a learning motivating and constructive way to the newborn caregivers.

Currently, care processes also aim to empower those who are being assisted or those who participate actively in the care [9]. In neonatology, guiding home caregivers of newborns gives an effective and continuous care, which helps to ease anxiety, insecurity, and complications in the health of the neonate.

An important tool in health care autonomy process is the educational booklet. It is a technology of tough, lightweight type, able to contemplate different areas of clinical practice [10]. This educational courseware that can be implemented to guidelines for discharge is an instrument that successfully benefits the health education process [11].

Thus, it is believed that most caregivers are not trained to early recognize the characteristic clinical signs of neonatal jaundice, nor empowered to develop preventive actions related to the disease. Therefore, this study aims to build an educational booklet on neonatal jaundice, intended for newborns caregivers.

\section{Methods}

This is a methodological research, focusing on the development of a booklet, which adopted the recommendations for the preparation of manuals on health care of the author Isabel Cristina Echer as the methodological reference [12].

According to the author above, steps for the construction of educational materials are necessary, highlighting: the search of the literature, the adequacy of literature information to the target population, choice of relevant information, as well as the illustration of selected content [12].

Thus, the first step in the construction of the booklet was carried out by searching the literature, through an integrative review, held in July and August 2015. For analysis of the scientific eviden- 
ce available in the literature on neonatal jaundice, the theoretical reference of Whittemore was used, which provides a synthesis of knowledge and the incorporation of the applicability of study results in practice [13].

For the review, the following guiding questions were elaborated: What are the concepts, signs, symptoms and causes of jaundice in newborns at term and preterm? What care is provided/oriented, outside the hospital for the newborns with jaundice?

The literature search included 852 publications produced in the past five years, contained in the following databases: Lilacs, Cochrane, Scopus, and PubMed. The descriptors used were "infants, newborn" OR "newborn" AND "neonatal jaundice" OR "Neonatal hyperbilirubinemia".

Then, the following inclusion criteria were applied: publications in Portuguese, English, and Spanish, available electronically in full in the selected databases. Thus, there were 13 articles included that addressed the issue of care for neonatal jaundice. Articles with more than five years of publication, publishing, manuals and publications in duplicate were excluded.

The second step for the construction of the booklet began with the selection of essential information on the subject and then the adequacy of vocabulary to facilitate understanding of the target audience. The transformation of the language of the information found in the literature improves the accessibility of the population [12].

The third stage included the selection of the relevant thematic, and it was based on the recommendations of the Neonatologists Nurses American Association, which states that written guidelines should include the concept, the main clinical manifestations, risk factors, the instructions on verification of jaundice and information about follow-up visits [4].

In the fourth methodological step, there was the illustration of selected content, with the prior prepa- ration of the booklet layout from the draft created by the authors of this study. The booklet should be attractive, objective and succinct to convey a comprehensive guidance on the subject to the people to whom it is intended [12].

Finally, the booklet of images was prepared by a professional specialized in the creation of illustrations, which addressed the content sequentially defined in the previous methodological steps. It is emphasized that the illustrator is also a nurse, which facilitated the creation of the drawings in the pedagogical teaching tool. Reproduction of material contemplated the idea of the outline developed by the authors, with colorful highlights for the most relevant content. The material completed this step was considered the first version of the booklet.

\section{Results}

The results were presented, considering the literature and the construction of the booklet.

The literature survey was carried out through an integrative review to search for online access, which revealed 852 publications produced in the last five years, related to the theme. Editorials, books, duplicate publications, and after reading the full articles and those who did not answer the research questions were excluded. Thus, the sample was defined with 13 publications. The following table shows the bibliographic material used. (Table 1)

After the selection of essential information in 13 publications, the content of the booklet was determined. The ideas presented were the definition of neonatal jaundice, risk factors, clinical manifestations and the warning signs of this health condition. The guidelines on what to do before the first signs/ symptoms and recommendations for follow-up consultations with health professionals to better assess the clinical status were also included.

It are noteworthy that the language of publications has been restructured to facilitate understan- 
Table 1. Bibliographic material according to database, year, country of the study, journal and title.

\begin{tabular}{|c|c|c|c|c|}
\hline Database & Year & Country & Journal & Title \\
\hline SCOPUS & 2013 & USA & The journal of Pediatrics & Black Race Is Not Protective Against Hazardous Bilirubin Levels \\
\hline COCHRANE & 2013 & USA & $\begin{array}{l}\text { Tropical Medicine and } \\
\text { Internacional Health }\end{array}$ & $\begin{array}{l}\text { Incidence of and risk factors for neonatal jaundice among } \\
\text { newborns in Southern Nepal }\end{array}$ \\
\hline SCOPUS & 2012 & India & $\begin{array}{l}\text { Indian Journal of Public } \\
\text { Health }\end{array}$ & $\begin{array}{l}\text { Glucose-6-Phosphate Dehydrogenase Screening of babies born } \\
\text { in a Tertiary care Hospital in West Bengal }\end{array}$ \\
\hline SCOPUS & 2012 & India & $\begin{array}{l}\text { Pediatrics and } \\
\text { International Child Health }\end{array}$ & Morbidity of $A B O$ haemolytic disease in the newborn \\
\hline LILACS & 2012 & India & West Indian med. I & $\begin{array}{l}\text { Epidemiology of neonatal Jaundice at the University Hospital of } \\
\text { the West Indies }\end{array}$ \\
\hline COCHRANE & 2012 & Venezuela & Invest Clin & $\begin{array}{l}\text { Diagnostic utility of the Kramer's method for the clinical } \\
\text { detection of neonatal hyperbilirubinemia }\end{array}$ \\
\hline SCOPUS & 2011 & Brazil & $\begin{array}{l}\text { Asian Pacific Journal of } \\
\text { Tropical Biomedicine }\end{array}$ & $\begin{array}{l}\text { Glucose- } 6 \text {-phosphate-dehydrogenase deficiency and its } \\
\text { correlation with other risk factors in jaundiced newborns in } \\
\text { Southern Brazil }\end{array}$ \\
\hline SCOPUS & 2011 & Malaysia & Malaysian J Pathol & $\begin{array}{l}\text { Prevalence of uridine glucuronosyl transferase 1A1 (UGT1A1) } \\
\text { mutations in Malay neonates with severe jaundice }\end{array}$ \\
\hline COCHRANE & 2011 & Turkey & Arch Gynecol Obstet & $\begin{array}{l}\text { Effect of anesthesiological strategies on neonatal bilirubin levels } \\
\text { during cesarean section: a prospective and randomized trial }\end{array}$ \\
\hline PUBMED & 2011 & France & $\begin{array}{l}\text { European Journal of } \\
\text { Obstetrics \& Gynecology } \\
\text { and Reproductive Biology }\end{array}$ & Atazanavir in pregnancy: impact on neonatal hyperbilirubinemia \\
\hline PUBMED & 2011 & Taiwan & $\begin{array}{l}\text { Pediatrics and } \\
\text { Neonatology }\end{array}$ & $\begin{array}{l}\text { Influence of Breast-feeding on Weight Loss, Jaundice, and } \\
\text { Waste Elimination in Neonates }\end{array}$ \\
\hline SCOPUS & 2010 & Malaysia & Pediatric Research & $\begin{array}{l}\text { A Polymorphic Mutation, C.-3279T>G, in the UGT1A1 Promoter } \\
\text { is a risk factor for neonatal jaundice in the malaysian population }\end{array}$ \\
\hline LILACS & 2010 & Brazil & $\begin{array}{l}\text { Rev. bras. Hematol. } \\
\text { Hemoter }\end{array}$ & $\begin{array}{l}\text { Erythrocyte glucose- } 6 \text {-phosphate dehydrogenase deficiency } \\
\text { in male newborn babies and its relationship with neonatal } \\
\text { jaundice }\end{array}$ \\
\hline
\end{tabular}

ding of the target audience. On each page, an idea was presented, including the essential information to the reader's understanding. An active voice and words with simple definitions were used. Jargon, abbreviations, and acronyms were not used, and using technical and scientific terms was avoided. (Figure 1)

The information of the booklet was highlighted by illustrations and explanatory sentences, following a logical sequence. A common situation in the family environment is designed to address the issue of neonatal jaundice. Initially, the main character, Fátima, is presented with the grandfather of the child,
João, as Pedro's caregivers. After observing changes in the neonate skin color, João's grandfather quite concerned alerts and asks her daughter. Then, Fátima clarifies the doubts of her father on the clinical condition of neonatal jaundice and emphasizes relevant information on the subject.

The illustrations contained in the booklet are always close to the text to which they refer, and drawings directed at an adult audience are used. It is noteworthy that the images were developed and edited by professional specialized in the creation of illustrations and approved by the authors of the study. 
Figure 1: Illustration of Baby Caring with jaundice Booklet.

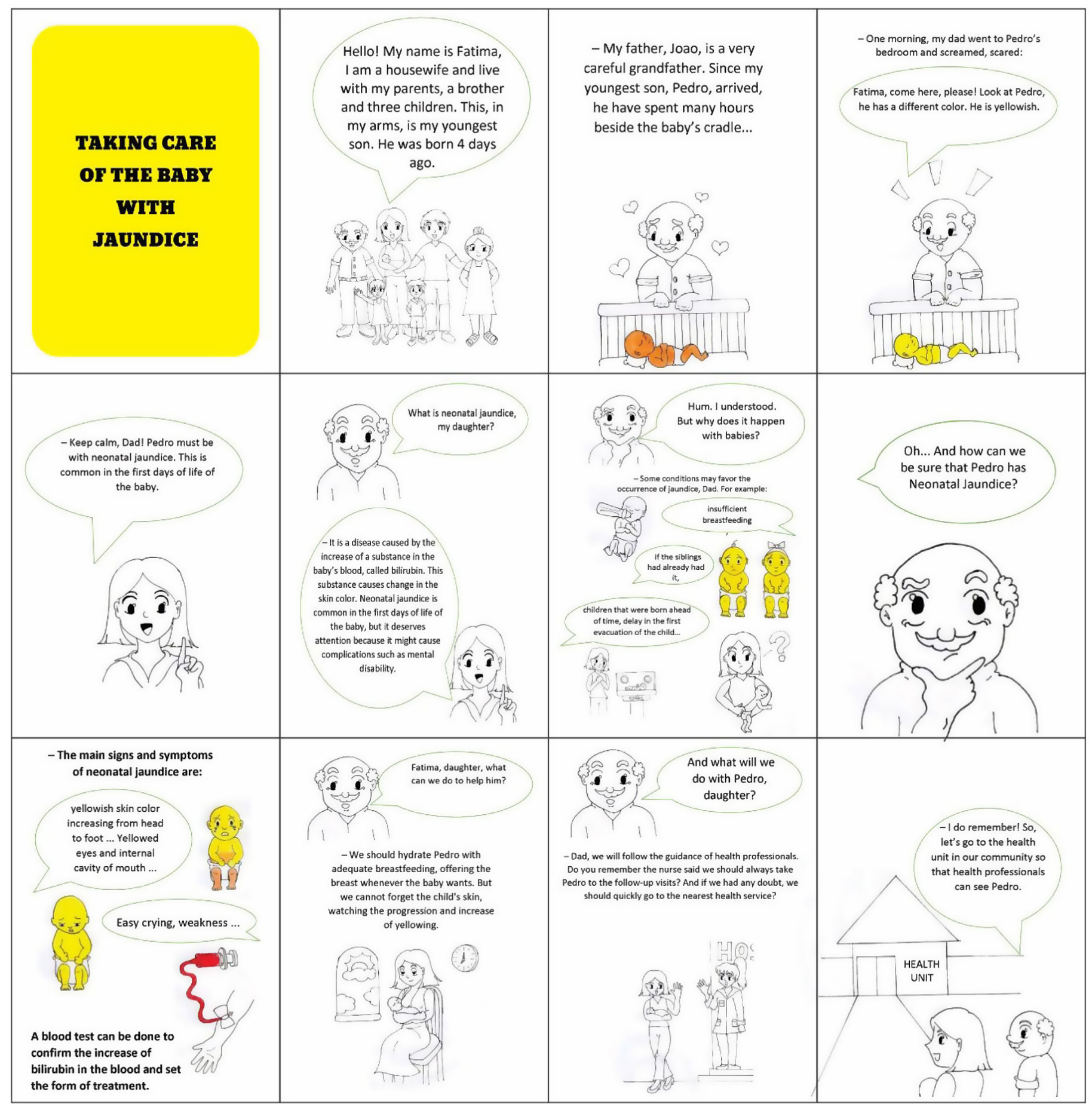

The booklet images were developed by an expert in creating illustrations. 
Regarding the concept of neonatal jaundice, there were simple ideas on elevated serum bilirubin levels, with consequent yellowing of the skin. It was emphasized that jaundice is a common health condition in the neonatal period and that its injury can trigger a complication of cognitive impairment [2-4].

The risk factors were presented with some situations that may predict neonatal jaundice, such as inadequate breastfeeding, the occurrence of neonatal jaundice previously in siblings, prematurity and the delay in the first elimination of meconium [14-15].

Regarding the main clinical manifestations, yellowing of the skin with cerebral-podalic progression was recorded, as well as also yellowing of the sclera and oral mucosa. Also, with warning signs of irritability and lethargy were highlighted [4]. The need for collecting laboratory test for serum bilirubin decision to set the appropriate treatment, and the importance of effective breastfeeding to ensure proper hydration of the newborn, were also highlighted.

Finally, care to minimize or prevent jaundice, orientation to seek a health professional for child's continuous evaluation, and the determination of the necessary therapeutic management was strengthened.

Each information was developed and presented in a page of the booklet, using explanatory illustrations that clarify the content of the displayed text. The booklet has a standard formatting size of 15 $\mathrm{cm}$ width and $21 \mathrm{~cm}$ in height and consists of eleven cover pages. Each page has a maximum of five images, totaling 20 illustrations.

\section{Discussion}

The choice of the theme for the educational booklet came from reflections on the importance of empowering caregivers in early identification of signs and symptoms of neonatal jaundice, due to the manifestation of this condition that has often occurred in the home environment, because of the brief stay of the newborn in the hospital after birth. The Neonatologists Nurses American Association of suggests that nurses constantly promote educational strategies to improve diagnostic procedures and treatment of hyperbilirubinemia [4].

Professional nurses need to be creative in the use of resources in the health education process. Thus, the educational booklet is presented as a pedagogical tool, capable of promoting integration through dialogue and enable the construction of multidimensional knowledge. Furthermore, the material has low production cost and can be easily available [16].

In the literature, it was identified only one educational material for publication on neonatal jaundice held in 2005, which addressed the use of educational technology in the practice of nursing care for mothers of newborns under phototherapy. In this study, it was found that the educational material effectively contributes to nursing care for mothers of newborns under phototherapy [17].

As a health worker and educator, the nurse acts as a key intermediate in the use of educational health technologies because he decodes knowledge and makes the strange content principle to clients in something common [16]. A study carried out to describe the experience in preparing booklets on education self-care of patients with diabetes showed that the written material has a valuable contribution to autonomy and skills development in the individual [18].

The booklet built in this study aims to guide caregivers about what is neonatal jaundice, as well as presenting its causes, complications and interventions required. The material has not only scientific fragments about pathology but also enables users on the recognition and development of actions at risk by a clear and objective language. The produced booklet is an alternative response to questions and patients wishes, and it can promote skills in care and provide a better quality of life. 
The construction of educational material requires an extensive literature search to support the proposed theme in a health technology. This process takes time for the selection of studies, ability to select relevant content and prior knowledge for the improvement of work. Therefore, it is noted that the teaching and educational material is an instrument coupled to nursing care practices, which allows the expansion of assistance over the premises of the hospital.

\section{Conclusions}

Nurses should pierce the inherent scientific capacity of the profession and perform artistic skills able to take on the challenge of educating for health. For this, they need to develop and use educational technology to provide humanized care and customer autonomy. Therefore, it is concluded that the booklet is a facilitator in the educational process to promote neonatal health.

Despite the magnitude of jaundice among newborns, studies on the construction of teaching materials are still limited, especially in booklets specialty of neonatology, as well as studies that focus on neonatal jaundice as a nursing phenomenon. Therefore, it is suggested further studies to the booklet validation by experts and caregivers to make it more representative of the actual specific customer needs.

\section{Conflict of interest}

The authors declare that there is no conflict of interest regarding the publication of this article

\section{References}

1. Sousa ABM, Sena DSL. Hiperbilirrubinemia neonatal: considerações sobre fisiopatogenia terapêuticas e complicações. Revista FACID: Ciência \& Vida [Internet]. 2012 Set [citado 2015 Dez 02] 8(2)17-25. Disponível em: http://favip.edu.br/arquivos/ REVISTA\%20FACID\%202012.2.pdf. Portuguese.
2. Scrafford CG, Mullany LC, Katz J, Khatry SK, LeClerq SC, Darmstadt GL, et al. Incidence of and risk factors for neonatal jaundice among newborns in southern Nepal. Trop Med Int Health. 2013 Nov; 18(11):1317-28. doi: 10.1111/tmi.12189. Epub 2013 Sep 23.

3. Afzal N, Qadir M, Qureshi S, Ali R, Ahmed S, Ahmad K. Urinary tract infection presenting as jaundice in neonates. J Pak Med Assoc [Internet]. 2012 Jul [cited 2015 Dez 06] 62(7):735-7. Available from: http://jpma.org.pk/PdfDownload/3566.pdf.

4. NANN Board of Directors. Prevention of acute bilirubin encephalopathy and kernicterus in newborns. Adv Neonatal Care. 2011 Oct; 11(5 Suppl):S3-9. doi: 10.1097/ ANC.0b013e31822efd64.

5. Henny-Harry C, Trotman H. Epidemiology of Neonatal Jaundice at the University Hospital of the West Indies. West Indian Med J [Internet]. 2012 Jan [cited 2016 Jan 11] 61 (1): 37-42. Available from: http://caribbean.scielo.org/pdf/wimj/v61n1/07.pdf.

6. Farhat R, Rajab M. Length of postnatal hospital stay in healthy newborns and re-hospitalization following early discharge. $\mathrm{N}$ Am J Med Sci [Internet]. 2011 Mar [cited 2015 Dez 12]; 3(3):146151. doi:10.4297/najms.2011.3146. Available from: http://www. ncbi.nlm.nih.gov/pmc/articles/PMC3336902/.

7. Ministério da Saúde. Informações de Saúde. Estatísticas Vitais. Mortalidade e Nascidos Vivos: nascidos vivos desde 1994. [Internet]. Brasil: Datasus [citado 2015 Nov 17]. Disponível em: http://tabnet.datasus.gov.br/cgi/tabcgi.exe?sim/cnv/obt10uf.def.

8. Costa HPF. Tempo de permanência hospitalar do recémnascido a termo saudável [Internet]. Brasil: Departamento de neonatologia, Sociedade Brasileira de Pediatria; Documento científico de maio de 2012. Disponível em: http://www.sbp. com.br/pdfs/doc_tempo-permanencia_rn.pdf. Portuguese.

9. Rosa J, Faccin C, Dalegrave D, Argenta C, Fransciscatto LHG. Ações educativas de assistência em enfermagem em ambiente hospitalar: a atenção a pais e familiares de neonatos em fototerapia. Revista de Enfermagem [Internet]. 2012 [citado 2015 Dez 18]; 8(8) 154-165. Disponível em: http://revistas.fw.uri. br/index.php/revistadeenfermagem/article/view/483/881. Portuguese.

10. Souza VB, Silva JS, Barros MC, Freitas, PSP. Tecnologias leves na saúde como potencializadores para qualidade da assistência às gestantes. Rev enferm UFPE [Internet]. 2014 Mai [citado 2015 Dez 20] 8(5):1388-9. Disponível em: http://www. revista.ufpe.br/revistaenfermagem/index.php/revista/article/ download/5023/9132. Portuguese.

11. Couto FF, Praça NS. Recém-nascido prematuro: suporte materno domiciliar para o cuidado. Rev Bras Enferm [Internet]. 2012 Jan/Fev [citado 2015 Dez 12] 65(1): 19-26. Disponível em: $\quad$ http://www.scielo.br/scielo.php?script=sci arttext\&pid =S0034-71672012000100003. Portuguese. 
12. Echer IC. Elaboração de manuais de orientação para o cuidado em saúde. Rev. Latino-am. Enfermagem [Internet]. 2005 Set/Out [cited 2015 Dez 5] 13(5) 7547-757. Available from: http://www.scielo.br/pdf/rlae/v13n5/v13n5a22.pdf. Portuguese.

13. Whittemore, R. Combining evidence in nursing research: methods and implications. Nurs Res [Internet]. 2005 Jan/Fev [cited 2015 Dez 2]; 54(1):56-62. PubMed PMID: 15695940. Available from: http://www.ncbi.n/m.nih.gov/pubmed/15695940.

14. Carvalho CG, Castro SM, Santin AP, Zaleski C, Carvalho FG, Giugliani R. Glucose-6-phosphate-dehydrogenase deficiency and its correlation with other risk factors in jaundiced newborns in Southern Brazil. Asian Pac J Trop Biomed [Internet]. 2011 Apr; 1(2): 110-113. doi: 10.1016/S2221-1691(11)60006-3. Available from: https://www.ncbi.nlm.nih.gov/pmc/articles/ PMC3609178/.15

15. Chen CF, Hsu MC, Shen CH, Wang CL, Chang SC, Wu KG, et al. Influence of Breast-feeding on Weight Loss, Jaundice, and Waste Elimination in Neonates. Pediatrics and Neonatology [Internet]. 2011 Apr [cited 2016 Mar 4] 52(2):85-92. doi:10.1016/j. pedneo.2011.02.010. Available from: http://www.pediatrneonatol.com/article/S1875-9572(11)00012-X/fulltext.

16. Barros EJL, Santos SSC, Gomes GC, Erdmann AL. Gerontotecnologia educativa voltada ao idoso estomizado à luz da complexidade. Rev Gaúcha Enferm [Internet]. 2012 Jun [citado 2016 Fev 20]; 33(2):95-101. doi: 10.1590/S198314472012000200014. Disponível em: http://www.scielo.br/scielo.php?script=sci arttext\&pid=S1983-14472012000200014. Portuguese.

17. Campos ACS, Cardoso MVLML. Tecnologia educativa para a prática do cuidado de enfermagem com mães de neonatos sob fototerapia. Texto contexto - enferm [Internet]. $2008 \mathrm{Mar}$ [citado 2016 Maio 31]; 17(1):36-44. Disponível em: http://www. scielo.br/scielo.php?script=sci arttext\&pid=\$01040707200800 0100004\&lng=en. Portuguese.

18. Torres HC, Candido NA, Alexandre LR, Pereira FL. O processo de elaboração de cartilhas para orientação do autocuidado no programa educativo em Diabetes. Rev bras enferm [Internet]. 2009 Mar/Abr [citado 2016 jan 20]; 62(2). Disponível em: http://www.scielo.br/scielo.php?script=sci_arttext\&pid $=$ S0034-71672009000200023. Portuguese.
Publish in International Archives of Medicine

International Archives of Medicine is an open access journal publishing articles encompassing all aspects of medical science and clinical practice. IAM is considered a megajournal with independent sections on all areas of medicine. IAM is a really international journal with authors and board members from all around the world. The journal is widely indexed and classified Q2 in category Medicine. 